\title{
Animal Models of Proliferative Vitreoretinopathy and Their Use in Pharmaceutical Investigations
}

\author{
Huiyuan Hou ${ }^{a}$ b Eric Nudleman ${ }^{a}$ Robert N. Weinreb ${ }^{a}$ \\ ${ }^{a}$ Department of Ophthalmology and Shiley Eye Institute, University of California, San Diego, CA, USA; ${ }^{b}$ Department \\ of Ophthalmology, Eye Institute of Chinese PLA, Xijing Hospital, Fourth Military Medical University, Xi'an, China
}

\section{Keywords}

Proliferative vitreoretinopathy · Animal model ·

Pharmacotherapy · Drug

\begin{abstract}
Animal models are indispensable for pharmaceutical investigations. However, investigators often have difficulty choosing the appropriate modal for their research. To provide a comprehensive and convenient source of information about animal models of proliferative vitreoretinopathy (PVR), the current review sorted and analyzed representative animal models for pharmacotherapy of PVR since 1976.
\end{abstract}

(c) 2018 S. Karger AG, Basel

\section{Introduction}

Proliferative vitreoretinopathy (PVR) is not a standalone disease, but it is considered the endpoint of a number of intraocular diseases. It is characterized by the formation of contractile membranes within the vitreous and along the preretinal and subretinal surfaces [1]. In spite of gradual improvements in surgical success rates over the past decades, PVR remains a major barrier to success- ful repair of retinal detachments $(\mathrm{RD})$, with an incidence of $5-11 \%$ [2]. Moreover, it is implicated in over $75 \%$ of postsurgical redetachments [2,3]. Multiple strategies, including surgery, have been developed to inhibit this disease process. PVR surgery can be challenging, even for experienced vitreoretinal surgeons, and anatomic success does not necessarily lead to functional improvement [2]. Adjunctive pharmacotherapy, with new molecules and delivery systems, offers promise for improved outcomes [3]. Animal models have an essential role in screening of various drugs [4]. For more than 40 years, lots of scientists and doctors have conducted relevant research. Landmark models, including a classic cell intravitreal injection model, introduction of blood components, surgical manipulation, and so forth, have been developed continuously. This review will focus on animal models used for drug screening and discuss their properties and limitations.

\section{Adjunctive Therapeutics for PVR}

Pharmacological adjuncts to surgical management of PVR usually target its cellular components and pathological processes [5]. Multiple medical treatments have been used to prevent inflammation (the first phase of PVR) and

\section{KARGER}

(c) 2018 S. Karger AG, Basel

E-Mail karger@karger.com

www.karger.com/ore
Huiyuan Hou

Shiley Eye Institute, University of California

9415 Campus Point Drive, La Jolla

San Diego, CA 92093-0946 (USA)

E-Mail huhou@ucsd.edu 
inhibit cell proliferation (the second phase) [1]. Tested medical agents include: (1) corticosteroids and other antiinflammatory agents [6-8]; (2) 5-fluorouracil, vincristine, doxorubicin, cisplatin, dactinomycin, bleomycin sulfate, etoposide, mitomycin, cytarabine, daunorubicin, adriamycin, 2'-benzoyloxycinnamaldehyde [9-11], methotrexate $[12,13]$, and other antineoplastic drugs to prevent the proliferative response of PVR; (3) retinoic acid [14], matrix metalloproteinase inhibitors [15], and other agents with specific antiproliferative targets; (4) compounds that specifically target growth factors or their pathways, such as hypericin (an inhibitor of the protein kinase $\mathrm{C}$ pathway [16]); herbimycin A [17] and dasatinib (tyrosine kinase inhibitors) [18]; tranilast (a potent inhibitor of transforming growth factor [TGF] $-\beta$ [19]), LY-364947 (a TGF- $\beta$ receptor 1 inhibitor [20]); taxol (a drug that stabilizes microtubules and may therefore inhibit cell contractility [21]); colchicine (inhibits the formation of microtubules as well as inhibiting fibroblast proliferation [22]) and suramin (an antiparasitic agent that interferes with growth factor binding [23]); and (5) other bioactive factors or compounds like octreotide [24] and resveratrol [25].

Combination therapies, which consist of 2 or more compounds targeting different steps in the proliferative and inflammatory responses that trigger PVR, have also been employed with the intent of obtain synergistic inhibition [2]. Different combinations of retinoic acid, retinol, daunorubicin, triamcinolone, and carmustine have been shown to be effective in PVR models [6, 26-28].

Although injection or perfusion of free drug into either the vitreous chamber or the subconjunctival space has proven effective in reducing the PVR incidence in humans as well as in animal models [29], a major limitation to the successful treatment of PVR using pharmacological adjuncts is the difficulty in achieving therapeutic drug levels in the microenvironment of the retinal surfaces over a sufficiently long period to adequately inhibit membrane formation. Single intravitreal injections of therapeutic agents have a relatively short half-life, which can be further shortened by vitrectomy, aphakia, and postoperative inflammation [9]. Therefore, sustained drug delivery systems, such as biodegradable polymers [10,30], silicone oil [26], and porous silicon [31], are being investigated [2].

In spite of considerable efforts to identify effective and safe adjunctive therapies, clinical success is still rare. This could be in part due to the lack of knowledge of the pharmacokinetics of these drugs when they are utilized for PVR prevention [1]. Therefore, comprehensive evaluation and investigation of any drug candidate in experimental models is essential.

\section{Design of PVR Animal Models for Pharmaceutical Investigation}

A comprehensive understanding of the pathobiology of PVR may eventually allow the development of targeted medical prophylaxis and/or adjunctive therapies. Experimental models of PVR that mimic human disease and can also be used for drug screening are needed.

PVR progresses in a predictable timeline [32] reminiscent of an anomalous wound-healing process. There is an initial inflammatory phase, a secondary proliferative response, and modulation of the scar which causes contraction $[14,33]$. The breakdown of the blood-ocular barrier caused by a retinal break that enables effusion of inflammatory cells (macrophages, leukocytes, and platelets) which release growth factors, including platelet-derived growth factor, TGF- $\beta$, and epidermal growth factor [34, 35]. Retinal breaks expose glial cells, retinal pigment epithelium (RPE), and other cells, triggering an exuberant healing process that is amplified by the intense inflammation. Upon loss of contact with the overlying retina, proliferation occurs as a rapid response with the involvement of RPE, glial cells (including Müller cells, astrocytes, and microglial cells), pericytes, endothelial cells, and macrophages $[36,37]$. Some of these cells transform into myofibroblasts and fibroblasts. Ultimately, vitreous, epiretinal, and subretinal membranes form. After a period of 8-10 weeks, these membranes often contract, placing tangential traction on the retina. The traction can pull the delicate retinal tissue into fixed folds that detach the photoreceptors from the underlying RPE [2]. If not relieved by surgical intervention, the traction can progress and result in stretch tears and subsequent rhegmatogenous detachments [38].

Several key factors in this process have been elucidated and have become the basis for the design of animal models for drug screening (Table 1). A number of cells, including RPE, leukocytes, macrophage, glial cells, fibroblast-like cells, and others, are implicated in the development of PVR [39]. They not only constitute the proliferative membrane but also serve as a source of growth factors. Therefore, many animal models are designed to introduce exogenous cells into the vitreous cavity. Cell types include autologous or homologous fibroblast cells including dermal $[40,41]$, conjunctival $[16,19]$, corneal [42] and choroidal fibroblast [21], autologous, homologous or heterologous RPE cells [43-45], and activated macrophages [39, 46]. Evidence suggests that the primary factor in the development of traction RD and membrane formation are platelet-derived factors [1]. Therefore, in- 
Table 1. Design of proliferative vitreoretinopathy animal models

\begin{tabular}{ll}
\hline Design & Rationale \\
\hline Cell intravitreal injection & $\begin{array}{l}\text { Introduction of cell composition of proliferation and } \\
\text { resource of growth factor } \\
\text { Introduction of platelet-derived factors }\end{array}$ \\
PRP or blood intravitreal injection & $\begin{array}{l}\text { Exposure of blood/retina-derived cells and factors } \\
\text { Artificial retinal break and blood-ocular barrier breakdown }\end{array}$ \\
$\begin{array}{l}\text { Intravitreal injection or transgenic expression growth factors/cytokines } \\
\text { Artificial vitreous disturbance }\end{array}$ & $\begin{array}{l}\text { Introduction of the necessary factors for PVR development } \\
\text { vitreous }\end{array}$ \\
Artificial chronic RD & Mimicry of advanced PVR \\
\hline
\end{tabular}

PRP, platelet rich plasma; PVR, proliferative vitreoretinopathy; RD, retinal detachment.

jection of blood products is often used to supplement injection of cells or surgeries [45, 47-50].

Retinal break is considered the critical factor that triggers the onset of PVR by exposing RPE cells to vitreous [51]. Several studies have identified clinical characteristics that are associated with the development of PVR, such as extensive or multiple retinal tears, vitreous hemorrhage, and multiple previous surgeries, all of which suggest a breakdown of the blood-ocular barrier that allows serum factors and cells to enter the eye $[1,52]$. PVR likely occurs as a result of interactions between cells derived from blood, and factors that enter the eye after the retinal tear [2]. Surgical manipulation, like retinotomy, cryopexy [53-55], dispase injection [4, 56, 57], and scleral injury, can be performed to mimic retinal damage and blood-ocular barrier breakdown [58, 59].

For PVR development, some factors must be present to transform the healing mechanism into an exaggerated response and produce hyperplastic growth of fibrotic tissue [1]. In addition, various cytokines appear to mediate the proliferative response [14]. Numerous growth factors and cytokines have been demonstrated as being involved in this process. Intravitreal injection or transgenic expression using a viral vector has been used to introduce growth factor or cytokines into eyes $[60,61]$.

Another factor related to the pathogenesis of PVR is the status of the vitreous. Physicochemical properties of normal vitreous prevent membrane formation [62, 63], and inhibitory factors that prevent the proliferation of endothelial cells, myofibrillar cells, and fibroblasts have been identified in normal vitreous [64]. Therefore, alteration of the normal vitreous properties appears to be a necessary requirement for the development of PVR. In animal PVR models, gas compression and vitrectomy are 2 main methods to disturb the vitreous, usually before in- travitreal injection or other surgical manipulations [49, 65-68]. A direct way to mimic advanced PVR is the development of chronic RD simply by subretinal injection $[69,70]$. This model develops some features of PVR, including activation of the Müller glia and extension of glial processes below the external limiting membrane [69].

\section{Application of PVR Models for Pharmaceutical Investigation}

\section{In vitro}

RPE cells and fibroblasts, important cell types involved in PVR pathogenesis $[5,71,72]$, and human PVR membrane-derived primary cultures [73] are commonly used as in vitro models. Several specific antiproliferative, antiinflammatory agents, including methotrexate [73], interleukin-4 [74], immunotoxins [75, 76], interferon-g [77], 5-fluorouracil, daunorubicin and others [78], are being investigated in these models. An obvious advantage of employing cells for drug screening is their practicability and controllability. However, the sensitivity of different cell types to certain drugs may be quite varied [78], and this variability may lead to difficulty with evaluation of drug efficiency.

\section{In vivo}

The earliest developed models of PVR often injected dermal fibroblasts to initiate PVR. Afterwards, other cell types, such as corneal, choroidal, and conjunctival fibroblasts, RPE cells, and macrophages, were introduced for PVR stimulation. These cell injection models are widely used. The significant advantage of a simple cell injection model is minimal invasion. In addition, certain growth factors and platelets can be injected simultaneously to en- 
hance the PVR-induced effect $[25,79]$. PVR features typically develop commensurate to the amount of cells injected and also relate to the injection medium [80]. In addition to the injection of different types of cells, other manipulations (such as platelet rich plasma/blood injection and surgical manipulation) are often used as they can be synergistic.

Artificial trauma, including scleral incision and other surgical manipulations, is also used to develop PVR models. Briefly, a standard 8-mm circumferential scleral incision is made through the pars plana avoiding the lens and retina. The prolapsed vitreous is resected and the wound repaired with $8-0$ sutures, followed by injection of autologous blood or ferrous iron [47, 81, 82]. Some models involve multiple surgical manipulations (e.g., gas compression, vitrectomy, cryotherapy, and retinotomy). Different combinations of cells or factors also can be injected along with these surgical manipulations to stimulate PVR. Recently, a chronic RD murine model was developed by subretinal injection to mimic the advanced stage of PVR [69, 70]. One thing should be kept in mind when artificial trauma is involved in model establishment: the PVR that occurs after penetrating trauma differs from PVR following $\mathrm{RD}$ surgery in many aspects. Therefore, model selection should be based on the targets of the specific drug tested.

Commonly used animal models are summarized in Table 2. Models with slight modifications based on other representative models resulting in inconspicuous model property changes were not included (i.e., gas compression replaced by hyaluronic acid compression). The publishing time of the earliest literature that the author could find in public literature resources using the key words of this review is shown as "establishment year," and RD is taken as the main clinical landmark.

Different animal species have their intrinsic pros and cons. Rabbit models have been widely used. Their large vitreous volume and the ease of manipulation with less risk of damage to the lens/retina are advantageous. However, rabbits' retinal structure including blood vessels and nerve fiber distribution is different from that of humans, resulting in limitations for pathologic and immunohistochemical examinations. In contrast, rodent models are less commonly employed. Although genetically modified murine species are widely available, their large lens size and small vitreous volume affect the feasibility of manipulation (e.g., intravitreal injection) and fundus examinations $[39,83]$. Pig models are rarely used; however, their eyes are similar in size to the human eye and this facilitates surgical manipulation. Moreover, their retina is holangiotic and they also have a cone-enriched area centralis which is similar to the human fovea $[55,84]$.

\section{Classification of Animal PVR in Pharmaceutical Investigations}

Fastenberg's classification is a commonly used classification of intact vitreous PVR models based on the clinical stages of PVR development, in which 5 stages are defined as follows [80]:

- stage 1: intravitreal membrane

- stage 2: focal traction, localized vascular changes, hyperemia, engorgement, dilatation, and blood vessel elevation

- stage 3: localized detachment of the medullar ray

- stage 4: extensive $\mathrm{RD}$, total medullar ray detachment, and peripapillary $\mathrm{RD}$

- stage 5: total RD, retinal folds, and holes

The following classification involving earlier stages was proposed for a vitreous compressed model [66] and simple cell intravitreal injection model [85]. Because of its fine scale, this grading system is particularly useful for quantifying pharmaceutic effects:

- stage 0: normal retina. The retina looks normal at this stage. Occasionally, fine intravitreal strands are seen extending from the injection site to the posterior retina.

- stage 1: surface wrinkling. The retina shows an irregular surface of the medullary wings or visual streaks with a beaten metal appearance.

- stage 2: mild pucker. Single or multiple small focal contractions resulting in a slight displacement of vessels toward the center are observed. These do not involve all of the medullary wing(s) and are not elevated. In rare cases, these lesions may cease development at this stage and disappear at a later time.

- stage 3: severe pucker. The preretinal contraction involves the whole area of the wing(s) and may consist of a single pucker or multiple puckers. The retina may be tented up but not by vitreous strands.

- stage 4: elevated pucker. At this stage, antero-posterior traction is observed, with the pucker(s) becoming elevated by vitreous strands.

- stage 5: partial RD. Detachment of the medullary wing occurs but involves only one wing. RD is seen with or without vitreous strands.

- stage 6: low detachment. RD involves both medullary wings, but the remainder of the avascular retina is attached.

- stage 7: total detachment. $\mathrm{RD}$ is seen over most of the avascular retina, usually with the appearance of a closed funnel detachment. In most cases retinal holes are visible. Sometimes unequivocal neovascularization appears from the disc or cryotherapy site. 
Table 2. In vivo models for pharmaceutical investigation

\begin{tabular}{|c|c|c|c|c|c|c|}
\hline \multirow[t]{2}{*}{ Model } & \multirow{2}{*}{$\begin{array}{l}\text { Establi- } \\
\text { shment } \\
\text { year }\end{array}$} & \multirow{2}{*}{$\begin{array}{l}\text { Ani- } \\
\text { mals }\end{array}$} & \multicolumn{2}{|l|}{ Clinical landmark } & \multirow[t]{2}{*}{ Concise common procedure } & \multirow{2}{*}{$\begin{array}{l}\text { Representative tested therapeutic } \\
\text { agents }\end{array}$} \\
\hline & & & $\begin{array}{l}\text { first time point of } \\
\text { RD being noticed }\end{array}$ & $\begin{array}{l}\text { percentage of RD at the end } \\
\text { of follow-up }\end{array}$ & & \\
\hline $\begin{array}{l}\text { Autologous dermal } \\
\text { fibroblast cell } \\
\text { injection }[40,96]\end{array}$ & 1976 & Rabbit & $\begin{array}{l}1 \times 10^{6} \text { cells, } \\
11-30 \text { days; } 3 \times 10^{6} \\
\text { cells, } 4 \text { days }\end{array}$ & $\begin{array}{l}4 \text { weeks: } 1 \times 10^{6} \text { cells, } 56 \% \text {; } \\
3 \times 10^{6 \text { cells }}, 100 \%\end{array}$ & $\begin{array}{l}\text { Injection of fibroblast cells into intact } \\
\text { eyes }\end{array}$ & $\begin{array}{l}\text { Triamcinolone [7], suramin [23], } \\
\text { and methotrexate [97] }\end{array}$ \\
\hline $\begin{array}{l}\text { Artificial trauma } \\
{[15,47,81,82,86]}\end{array}$ & 1979 & Rabbit & 12 days & $\begin{array}{l}6 \text { weeks: } 0.4 \mathrm{~mL} \text { blood, } 78- \\
82 \% ; 0.2 \mathrm{~mL} \text { blood, } 43 \% ; 0.1 \\
\mathrm{~mL} \text { blood, } 0 \% ; 200 \mu \mathrm{g} \text { elemen- } \\
\text { tal iron, } 100 \% ; 100 \mu \mathrm{g} \text { elemen- } \\
\text { tal iron, } 100 \% ; 50 \mu \mathrm{g} \text { elemen- } \\
\text { tal iron, } 0 \%\end{array}$ & $\begin{array}{l}\text { Vitrectomy, autologous blood/ferrous } \\
\text { iron injection }\end{array}$ & $\begin{array}{l}\text { Naproxen and 5-FU codrug, } \\
\text { prinomastat [15], and pirfeni- } \\
\text { done [98] }\end{array}$ \\
\hline $\begin{array}{l}\text { Homologous dermal/ } \\
\text { corneal/choroidal/ } \\
\text { conjunctival fibroblast } \\
\text { injection }[99,100]\end{array}$ & 1982 & Rabbit & $\begin{array}{l}7 \times 10^{5} \text { cells, } \\
1 \text { day; } 2.5 \times 10^{5} \text { cells, } \\
1 \text { day }\end{array}$ & $\begin{array}{l}4 \text { weeks: } 2.5 \times 10^{5} \text { cells, } 25- \\
90 \% ; 5 \text { weeks: } 7 \times 10^{5} \text { cells, } \\
\sim 60 \%\end{array}$ & $\begin{array}{l}\text { Injection of fibroblasts into intact } \\
\text { eyes }\end{array}$ & $\begin{array}{l}\text { Hypericin [16], herbimycin [17], } \\
\text { taxol [21, 42], and tranilast [19] }\end{array}$ \\
\hline $\begin{array}{l}\text { Homologous RPE } \\
\text { cell injection [44] }\end{array}$ & 1982 & Rabbit & 2 weeks & 4 weeks: $100 \%$ & $\begin{array}{l}\text { Injection of RPE cells into intact } \\
\text { eyes }\end{array}$ & Disintegrins [88] and DNR [101] \\
\hline $\begin{array}{l}\text { Homologous dermal } \\
\text { fibroblast injection }+ \\
\text { vitrectomy [41] }\end{array}$ & 1983 & Rabbit & $\begin{array}{l}\text { Without silicone oil, } \\
14 \text { days }\end{array}$ & $\begin{array}{l}4 \text { weeks: without silicon oil, } \\
100 \% \text {; with silicon oil, } 50 \%\end{array}$ & $\begin{array}{l}\text { Transcleral cryopexy; } \\
\text { after } 2 \text { weeks, vitrectomy; after } 2 \\
\text { weeks, fibroblast injection }\end{array}$ & Taxol [42] \\
\hline $\begin{array}{l}\text { Gas compression }+ \\
\text { homologous fibroblast } \\
\text { injection }[66,67,102]\end{array}$ & 1986 & Rabbit & $\begin{array}{l}25,000 \text { cells, } \\
4 \text { days; } 50,000 \text { cells, } \\
2 \text { days; } 100,000 \text { cells, } \\
7 \text { days }\end{array}$ & $\begin{array}{l}4 \text { weeks: } 25,000 \text { cells, } 88-91 \% \text {; } \\
50,000 \text { cells, } 100 \% ; 100,000 \\
\text { cells, } 50 \%\end{array}$ & $\begin{array}{l}\text { Perfluoropropane or sulfur } \\
\text { hexafluoride gas injection; after 7-10 } \\
\text { days, fibroblast cell injection }\end{array}$ & $\begin{array}{l}\text { Retinoic acid [30], retinoic acid } \\
{[26], \text { and carmustine }[27]}\end{array}$ \\
\hline $\begin{array}{l}\text { Activated macrophages } \\
{[46,103]}\end{array}$ & 1987 & Rabbit & 2 weeks & 6-9 weeks, 38\% RD & $\begin{array}{l}\text { Injection of } 8 \times 10^{5} \text { homologous } \\
\text { macrophages into intact eyes }\end{array}$ & $\begin{array}{l}\text { Triamcinolone [6] and a combi- } \\
\text { nation of DNR and triamcino- } \\
\text { lone [28] }\end{array}$ \\
\hline $\begin{array}{l}\text { Heterologous RPE cell } \\
\text { injection [104-106] }\end{array}$ & 1987 & Rabbit & 7 days & 4 weeks, $75 \%$ & $\begin{array}{l}\text { Injection of human, bovine, or rat } \\
\text { RPE cells into intact eyes }\end{array}$ & 5-FU [105] \\
\hline $\begin{array}{l}\text { Multiple surgical } \\
\text { manipulations [107] }\end{array}$ & 1991 & Rabbit & N/A & $\begin{array}{l}4-12 \text { weeks, PVR developed } \\
\text { in } 90 \% \text { of eyes }\end{array}$ & $\begin{array}{l}\text { Pars plana lensectomy, core } \\
\text { vitrectomy, and penetrating retinal } \\
\text { endodiathermy }\end{array}$ & $\begin{array}{l}\text { Triamcinolone and 5-FU codrug } \\
{[108]}\end{array}$ \\
\hline $\begin{array}{l}\text { Homologous } \\
\text { conjunctival fibroblasts } \\
\text { injection + PRP [49] }\end{array}$ & 1995 & Rabbit & 1 day & 29 days, $100 \%$ & $\begin{array}{l}\text { Injection of } 1 \times 10^{5} \text { conjunctival } \\
\text { fibroblasts and PRP }(0.1 \mathrm{~mL}, 75,000 \\
\text { platelets })\end{array}$ & $\begin{array}{l}\text { DNR encapsulated in liposome } \\
{[109]}\end{array}$ \\
\hline $\begin{array}{l}\text { Dispase injection } \\
{[56,57,87]}\end{array}$ & 1998 & $\begin{array}{l}\text { Rabbit, } \\
\text { guinea pig, } \\
\text { and mouse }\end{array}$ & $\mathrm{N} / \mathrm{A}$ & $\begin{array}{l}\text { Overall, with increased doses } \\
\text { of dispase, the severity of PVR } \\
\text { increased }\end{array}$ & $\begin{array}{l}\text { Injection of a different dose of dispase } \\
\text { into the subretinal space or vitreous }\end{array}$ & $\begin{array}{l}\text { Ribozyme [87] and octreotide } \\
\text { [24] }\end{array}$ \\
\hline $\begin{array}{l}\text { Gas compression + homo- } \\
\text { logous RPE } \\
\text { injection }[11,110]\end{array}$ & 2002 & Rabbit & 7 days & 4 weeks, $72.7 \%$ & $\begin{array}{l}\text { Perfluorocarbon or sulfur hexafluoride } \\
\text { gas injection; gas-fluid exchange; } \\
7-10 \text { days later, injection of } \\
(1-2) \times 10^{5} \text { or } 5 \times 10^{4} \text { RPE cells }\end{array}$ & $\begin{array}{l}\text { 2'-benzoyl-oxycinnamaldehyde } \\
\text { [11], doxorubicin [110], and } \\
\text { dexamethasone [3] }\end{array}$ \\
\hline $\begin{array}{l}\text { Vitrectomy + } \\
\text { artificial RD + RPE } \\
\text { cells injection [84] }\end{array}$ & 2012 & Swine & 3 days & 14 days, $100 \%$ & $\begin{array}{l}\text { Pars plana vitrectomy followed by } \\
\text { subretinal injection and intravitreal } \\
\text { injection of RPE cells }\end{array}$ & Dasatinib [18] \\
\hline $\begin{array}{l}\text { Homologous RPE } \\
\text { cells + PDGF-BB } \\
\text { injection [25] }\end{array}$ & 2015 & Rabbit & 7 days & 14 days, $100 \%$ & $\begin{array}{l}\text { Vitrectomy and injection of } 1.5 \times 10^{5} \\
\text { RPE cells and } 50 \text { ng PDGF-BB in } 100 \\
\text { uL PBS }\end{array}$ & Resveratrol [25] \\
\hline
\end{tabular}

RPE, retinal pigment epithelium. PRP, platelet-rich plasma; 5-FU, 5-fluorouracil; DNR, daunorubicin; PLGA, polylactic-co-glycolic acid; PDGF-BB, BB isoform of platelet-derived growth factor.

In a trauma model, the surgical procedure is usually followed by an intravitreal injection of autologous blood, which precludes a reliable clinical observation. Therefore, in addition to a clinical indirect microscopic examination, a detailed fundus evaluation of the enucleated eye under a dissecting microscopy is used for PVR grading as follows [86]:

- stage 0: attached without evidence of fibrous ingrowth. - stage 1: attached with minimal traction elevation confined to the medullary ray. Mild fibrous ingrowth is 
present upon scleral depression. Occasionally a "clothesline" type of fold is evident within the posterior ray, but the retina surrounding the ray remains attached.

- stage 2: up to $50 \%$ of the retina is detached (moderate tractional elevation), usually directly surrounding the ray. Prominent anteroposterior traction involving the disc and medullary ray is evident. Prominent fibrous ingrowth is present, with faint bands connecting the peripheral ray fibrous mass to the disc or ray. The retinal vessels are dilated without overt neovascularization.

- stage 3: between $50-100 \%$ of the retina is detached (severe $\mathrm{RD}$ ), usually associated with an open funnel configuration. Fibrous ingrowth from the wound is severe, and the peripheral retina and ray are drawn towards the fibrous mass.

- stage 4: $100 \%$ of the retina is detached, associated with a closed funnel configuration. Fibrous ingrowth is severe, with obvious dragging of the retina causing prominent retinal folds.

Besides, there are also grading methods, especially for dispase injection-induced PVR [87], swine models [84], and tractional RD $[65,88]$.

\section{Limitation of Current Animal Models, Research Needs, and Future Directions}

Animal models have an important role in evaluating various pharmacologic therapies for PVR. However, there are important clinical and pathological differences between the models of PVR and human disease, which deserve careful consideration when they are used for drug screening.

Most commonly, PVR animal models have relied on the addition of cells or factors reported to be found in human PVR and often include other manipulations, such as gas compression and vitrectomy. The models in which PVR is stimulated by intravitreal injection of fibroblasts, RPE cells, or macrophages are widely employed for testing of new therapeutic agents. However, these models are flawed because they introduce large numbers of cells. Moreover, they do not take into account the early crucial steps in PVR development, including cellular transformation and proliferation $[53,89,90]$. If the inhibitory effects of any drugs are tested, injected drugs may affect not only the development of PVR but also the injected cells themselves directly. Thus, inactivated and/or dying cells can not induce PVR resulting in welcome results. Among the cell injection models, fibroblast injection give rise to doubt. Dermal, corneal, or conjunctival fibroblasts are not involved with the pathogenesis of human PVR. In contrast, injection models that utilize cultured RPE cells and macrophages are more relevant to human disease [80]. However, the macrophage injection model does not expose RPE cells, which are thought to have a critical role in the development of human PVR. Further, the lack of trauma associated with retinal surgery in animals implies the possibility of fewer infiltrating leukocytes and their associated cytokines $[35,80]$.

Blood exposure can influence the pathogenesis of PVR, both in terms of the rapidity of PVR progression and in terms of membrane formation [80]. Human PVR may be associated with intraocular bleeding [80]. Moreover, the introduction of blood hinders the observation of early features of PVR. Another model that implicates severe media opacity (vitreous hemorrhage and cataract) is the dispase injection model, in which the incidence of vitreous hemorrhage and cataracts increases with higher doses $[56,91]$.

The time course of the disease is an important aspect of the pathobiology of PVR that needs to be addressed to standardize the testing of various pharmaceutical agents [1]. Although there is a variable time course for different models, the progression of PVR in animal models is generally much faster than in humans. The usual development of PVR in the base model starts quite early, when membranes and strands are seen. $\mathrm{RD}$ may occur within days and progresses to a full development of PVR in most models in 4 weeks. The time course of membrane formation and $\mathrm{RD}$ in cell injection models depends on the source, type, and amount of cells introduced [80] Also, the injection medium and subsequent blood product injection can influence the results [80]. The rapid disease progression makes complete inhibition of PVR in the animal model a challenge because the PVR can become quite severe quickly before any pharmacological treatment can be effective. Compared to other cell types, PVR development with the macrophage injection model seems slower. The chronic RD model, in contrast, bypasses all early pathologic steps $[69,70]$. Thus, use of this model in drug screening is rare. However, this model can still be useful as its fibrosis feature could be an appropriate target for antifibrotic agents. One pitfall in the design of some animal models is a lengthy follow-up interval, which may be too long to observe the earliest pathologic changes [18].

Efforts have been directed toward developing models that more closely resemble the human pathophysiologic 
condition, placing more emphasis on the role of intraocular inflammation, wound healing, and the presence of growth factors than the introduction of external cells into the eye $[53,55,68,84,92]$. But those models usually involve surgical manipulation with reproducibility, to a large extent, depending on the operative skills of the surgeon. Transgenic models in which overexpression of various growth factors in the photoreceptor cells leads to traction detachment of the retina $[93,94]$ are not suitable for drug screening, because forced alteration of the cytokine expression profile likely affects the signal transduction system [95] that may be a target of the tested therapeutic agent. Induction of PVR by injection of dispase is likely to stimulate retinal glial cells to migrate toward the subretinal space [95], but it may be complicated by vitreous hemorrhage, haze, and cataract $[56,57,87]$.

Considering the limitations of available models, it is clear that new improved models are needed. One aspect of the ideal model is stimulation of the animal retina to produce the regulatory factors of the wound-healing process instead of introduction of exogenous factors from injected cells, virus, or free factors [1]. With these factors, a spontaneous epithelial-mesenchymal transition of cells like RPE and macrophages after RD can be mimicked [39, 95]. Taking reproducibility and ease of establishment of the model into account, less complicated manipulations would be advantageous.

\section{Conclusion}

Although the current management of PVR is primarily surgical, there is an ongoing effort with experimental models to discover adjuvant therapies that might inhibit the development of postoperative PVR and lead to better patient outcomes [2]. However, an agent that fully prevents the development of PVR is not yet available. Existing experimental models of PVR all have limitations that limit their relevance for drug screening. Therefore, optimization of experimental models for PVR continues to be a challenge.

\section{Acknowledgment}

This review article was supported in part by the National Natural Science Foundation of China (No. 81200708).

\section{Disclosure Statement}

Huiyuan Hou has nothing to disclose. Eric Nudleman: consultant/advisor - Allergan and Visunex Medical Systems. Robert N. Weinreb: consultant/advisor - Alcon, Allergan, Bausch \& Lomb, Carl Zeiss Meditec, Sensimed, and Topcon; grant support - Heidelberg Engineering, Genentech, Optovue, and Unity. The authors declare no conflict of interests.

\section{References}

1 Pastor JC: Proliferative vitreoretinopathy: an overview. Surv Ophthalmol 1998;43:3-18.

2 Sun JK, Arroyo JG: Adjunctive therapies for proliferative vitreoretinopathy. Int Ophthalmol Clin 2004;44:1-10.

3 Chiquet C, Rouberol F: Proliferative vitreoretinopathy: prophylactic treatment. J Fr Ophtalmol 2014;37:737-743.

4 Markus B, Pato Z, Sarang Z, Albert R, Tozser J, Petrovski G, Csosz E: The proteomic profile of a mouse model of proliferative vitreoretinopathy. FEBS Open Bio 2017;7:1166-1177.

5 Charteris DG: Proliferative vitreoretinopathy: pathobiology, surgical management, and adjunctive treatment. Br J Ophthalmol 1995; 79:953-960.

-6 Hui YN, Liang HC, Cai YS, Kirchhof B, Heimann K: Corticosteroids and daunomycin in the prevention of experimental proliferative vitreoretinopathy induced by macrophages. Graefes Arch Clin Exp Ophthalmol 1993;231: 109-114.
7 Tano Y, Chandler D, Machemer R: Treatment of intraocular proliferation with intravitreal injection of triamcinolone acetonide. Am J Ophthalmol 1980;90:810-816.

$\checkmark 8$ Rubsamen PE, Cousins SW: Therapeutic effect of periocular corticosteroids in experimental proliferative vitreoretinopathy. Retina 1997;17:44-50.

-9 Peyman GA, Schulman J: Proliferative vitreoretinopathy and chemotherapeutic agents. Surv Ophthalmol 1985;29:434-442.

10 Moritera T, Ogura Y, Yoshimura N, Honda Y, Wada R, Hyon SH, Ikada Y: Biodegradable microspheres containing adriamycin in the treatment of proliferative vitreoretinopathy. Invest Ophthalmol Vis Sci 1992;33:31253130.

11 Lee JJ, Park JK, Kim YT, Kwon BM, Kang SG, Yoo YD, Yu YS, Chung H: Effect of 2'-benzoyl-oxycinnamaldehyde on RPE cells in vitro and in an experimental proliferative vitreoretinopathy model. Invest Ophthalmol Vis Sci 2002;43:3117-3124.
12 Sadaka A, Sisk RA, Osher JM, Toygar O, Duncan MK, Riemann CD: Intravitreal methotrexate infusion for proliferative vitreoretinopathy. Clin Ophthalmol 2016;10:18111817.

13 Hardwig PW, Pulido JS, Bakri SJ: The safety of intraocular methotrexate in silicone-filled eyes. Retina 2008;28:1082-1086.

14 Kim IK, Arroyo JG: Mechanisms in proliferative vitreoretinopathy. Ophthalmol Clin North Am 2002;15:81-86.

15 Ozerdem U, Mach-Hofacre B, Keefe K, Pham T, Soules K, Appelt K, Freeman WR: The effect of prinomastat (AG3340), a synthetic inhibitor of matrix metalloproteinases, on posttraumatic proliferative vitreoretinopathy. Ophthalmic Res 2001;33:20-23.

16 Tahara YR, Sakamoto TR, Oshima YR, Ishibashi TR, Inomata HR, Murata TR, Hinton DR, Ryan SJ: The antidepressant hypericin inhibits progression of experimental proliferative vitreoretinopathy. Curr Eye Res 1999;19:323-329. 
17 Imai K, Loewenstein A, Koroma B, Grebe R, de Juan E Jr: Herbimycin A in the treatment of experimental proliferative vitreoretinopathy: toxicity and efficacy study. Graefes Arch Clin Exp Ophthalmol 2000;238:440-447.

- 18 Umazume K, Liu L, Scott PA, de Castro JP, McDonald K, Kaplan HJ, Tamiya S: Inhibition of PVR with a tyrosine kinase inhibitor, dasatinib, in the swine. Invest Ophthalmol Vis Sci 2013;54:1150-1159.

19 Ito S, Sakamoto T, Tahara Y, Goto Y, Akazawa K, Ishibashi T, Inomata H: The effect of tranilast on experimental proliferative vitreoretinopathy. Graefes Arch Clin Exp Ophthalmol 1999;237:691-696.

-20 Nassar K, Grisanti S, Tura A, Luke J, Luke M, Soliman M, Grisanti S: A TGF-beta receptor 1 inhibitor for prevention of proliferative vitreoretinopathy. Exp Eye Res 2014;123:72-86.

-21 van Bockxmeer FM, Martin CE, Thompson DE, Constable IJ: Taxol for the treatment of proliferative vitreoretinopathy. Invest Ophthalmol Vis Sci 1985;26:1140-1147.

22 Berman DH, Gombos GM: Proliferative vitreoretinopathy: does oral low-dose colchicine have an inhibitory effect? A controlled study in humans. Ophthalmic Surg 1989;20:268272.

-23 de Souza OF, Sakamoto T, Kimura H, Koda RP, Gabrielian K, Spee C, Ryan SJ: Inhibition of experimental proliferative vitreoretinopathy in rabbits by suramin. Ophthalmologica 1995;209:212-216.

-24 Evren O, Turgut B, Celiker U, Ates K: The impact of octreotide in experimental proliferative vitreoretinopathy. Indian J Ophthalmol 2013;61:109-114.

- 25 Ishikawa K, He S, Terasaki H, Nazari H, Zhang H, Spee C, Kannan R, Hinton DR: Resveratrol inhibits epithelial-mesenchymal transition of retinal pigment epithelium and development of proliferative vitreoretinopathy. Sci Rep 2015;5:16386.

-26 Araiz JJ, Refojo MF, Arroyo MH, Leong FL, Albert DM, Tolentino FI: Antiproliferative effect of retinoic acid in intravitreous silicone oil in an animal model of proliferative vitreoretinopathy. Invest Ophthalmol Vis Sci 1993; 34:522-530.

27 Arroyo MH, Refojo MF, Araiz JJ, Tolentino FI, Cajita VN, Elner VM: Silicone oil as a delivery vehicle for $\mathrm{BCNU}$ in rabbit proliferative vitreoretinopathy. Retina 1993;13:245-250.

$\checkmark 28$ Hui YN, Hu D: Prevention of experimental proliferative vitreoretinopathy with daunomycin and triamcinolone based on the time course of the disease. Graefes Arch Clin Exp Ophthalmol 1999;237:601-605.

29 Tani P, Robertson DM, Langworthy A: Prognosis for central vision and anatomic reattachment in rhegmatogenous retinal detachment with macula detached. Am J Ophthalmol 1981;92:611-620.

30 Giordano GG, Refojo MF, Arroyo MH: Sustained delivery of retinoic acid from microspheres of biodegradable polymer in PVR. Invest Ophthalmol Vis Sci 1993;34:2743-2751.
1 Anglin EJ, Cheng L, Freeman WR, Sailor MJ: Porous silicon in drug delivery devices and materials. Adv Drug Deliv Rev 2008;60:12661277.

32 Mietz H, Heimann K: Onset and recurrence of proliferative vitreoretinopathy in various vitreoretinal disease. Br J Ophthalmol 1995; 79:874-877.

33 Wilkins RB, Kulwin DR: Wendell L. Hughes lecture: wound healing. Ophthalmology 1979; 86:507-510.

34 Wiedemann P: Growth factors in retinal diseases: proliferative vitreoretinopathy, proliferative diabetic retinopathy, and retinal degeneration. Surv Ophthalmol 1992;36:373384.

35 Moysidis SN, Thanos A, Vavvas DG: Mechanisms of inflammation in proliferative vitreoretinopathy: from bench to bedside. Mediators Inflamm 2012;2012:815937.

- 36 Fisher SK, Erickson PA, Lewis GP, Anderson DH: Intraretinal proliferation induced by retinal detachment. Invest Ophthalmol Vis Sci 1991;32:1739-1748.

37 Vinores SA, Seo MS, Derevjanik NL, Campochiaro PA: Photoreceptor-specific overexpression of platelet-derived growth factor induces proliferation of endothelial cells, pericytes, and glial cells and aberrant vascular development: an ultrastructural and immunocytochemical study. Brain Res Dev Brain Res 2003;140:169-183.

- 38 Campochiaro PA: Pathogenic mechanisms in proliferative vitreoretinopathy. Arch Ophthalmol 1997;115:237-241.

39 Lin ML, Li YP, Li ZR, Lin JX, Zhou XL, Liang D: Macrophages acquire fibroblast characteristics in a rat model of proliferative vitreoretinopathy. Ophthalmic Res 2011;45:180-190.

40 Algvere P, Kock E: Experimental fibroplasia in the rabbit vitreous: retinal detachment induced by autologous fibroblasts. Albrecht Von Graefes Arch Klin Exp Ophthalmol 1976;199:215-222.

41 Gonvers M, Thresher R: Temporary use of silicone oil in the treatment of proliferative vitreoretinopathy: an experimental study with a new animal model. Graefes Arch Clin Exp Ophthalmol 1983;221:46-53.

42 Daniels SA, Coonley KG, Yoshizumi MO: Taxol treatment of experimental proliferative vitreoretinopathy. Graefes Arch Clin Exp Ophthalmol 1990;228:513-516.

43 Radtke ND, Tano Y, Chandler D, Machemer R: Simulation of massive periretinal proliferation by autotransplantation of retinal pigment epithelial cells in rabbits. Am J Ophthalmol 1981;91:76-87.

44 Fastenberg DM, Diddie KR, Sorgente N, Ryan SJ: A comparison of different cellular inocula in an experimental model of massive periretinal proliferation. Am J Ophthalmol 1982;93: 559-564.
45 Lei H, Rheaume MA, Velez G, Mukai S, Kazlauskas A: Expression of PDGFRalpha is a determinant of the PVR potential of ARPE19 cells. Invest Ophthalmol Vis Sci 2011;52: 5016-5021.

46 Hui YN, Sorgente N, Ryan SJ: Posterior vitreous separation and retinal detachment induced by macrophages. Graefes Arch Clin Exp Ophthalmol 1987;225:279-284.

47 Vergara O, Ogden T, Ryan S: Posterior penetrating injury in the rabbit eye: effect of blood and ferrous ions. Exp Eye Res 1989;49: 1115-1126.

-48 Andrews A, Balciunaite E, Leong FL, Tallquist M, Soriano P, Refojo M, Kazlauskas A: Platelet-derived growth factor plays a key role in proliferative vitreoretinopathy. Invest Ophthalmol Vis Sci 1999;40:2683-2689.

-49 Nakagawa M, Refojo MF, Marin JF, Doi M, Tolentino FI: Retinoic acid in silicone and silicone-fluorosilicone copolymer oils in a rabbit model of proliferative vitreoretinopathy. Invest Ophthalmol Vis Sci 1995;36:23882395.

50 Lei H, Hovland P, Velez G, Haran A, Gilbertson D, Hirose T, Kazlauskas A: A potential role for PDGF-C in experimental and clinical proliferative vitreoretinopathy. Invest Ophthalmol Vis Sci 2007;48:2335-2342.

51 Cowley M, Conway BP, Campochiaro PA, Kaiser D, Gaskin H: Clinical risk factors for proliferative vitreoretinopathy. Arch Ophthalmol 1989;107:1147-1151.

52 Miller B, Miller H, Patterson R, Ryan SJ: Retinal wound healing: cellular activity at the vitreoretinal interface. Arch Ophthalmol 1986; 104:281-285.

-53 Goldaracena MB, Garcia-Layana A, Pastor JC, Saornil MA, de la Fuente F, Gayoso MJ: The role of retinotomy in an experimental rabbit model of proliferative vitreoretinopathy. Curr Eye Res 1997;16:422-427.

54 Campochiaro PA, Gaskin HC, Vinores SA Retinal cryopexy stimulates traction retinal detachment formation in the presence of an ocular wound. Arch Ophthalmol 1987;105: $1567-1570$

55 Garcia-Layana A, Pastor JC, Saornil MA, Gonzalez G: Porcine model of proliferative vitreoretinopathy with platelets. Curr Eye Res 1997; 16:556-563.

56 Frenzel EM, Neely KA, Walsh AW, Cameron JD, Gregerson DS: A new model of proliferative vitreoretinopathy. Invest Ophthalmol V is Sci 1998;39:2157-2164.

57 Kralinger MT, Kieselbach GF, Voigt M, Hayden B, Hernandez E, Fernandez V, Parel JM: Experimental model for proliferative vitreoretinopathy by intravitreal dispase: limited by zonulolysis and cataract. Ophthalmologica 2006;220:211-216.

58 Hsu HT, Ryan SJ: Natural history of penetrating ocular injury with retinal laceration in the monkey. Graefes Arch Clin Exp Ophthalmol 1986;224:1-6. 
59 Cleary PE, Ryan SJ: Vitrectomy in penetrating eye injury: results of a controlled trial of vitrectomy in an experimental posterior penetrating eye injury in the rhesus monkey. Arch Ophthalmol 1981;99:287-292.

60 Liou GI, Pakalnis VA, Matragoon S, Samuel S, Behzadian MA, Baker J, Khalil IE, Roon P, Caldwell RB, Hunt RC, Marcus DM: HGF regulation of RPE proliferation in an IL-1be$\mathrm{ta} /$ retinal hole-induced rabbit model of PVR. Mol Vis 2002;8:494-501.

-61 Jin M, Chen Y, He S, Ryan SJ, Hinton DR: Hepatocyte growth factor and its role in the pathogenesis of retinal detachment. Invest Ophthalmol Vis Sci 2004;45:323-329.

62 Ryan SJ: The pathophysiology of proliferative vitreoretinopathy in its management. Am J Ophthalmol 1985;100:188-193.

63 Vidaurri-Leal J, Hohman R, Glaser BM: Effect of vitreous on morphologic characteristics of retinal pigment epithelial cells: a new approach to the study of proliferative vitreoretinopathy. Arch Ophthalmol 1984;102:12201223.

64 Raymond L, Jacobson B: Isolation and identification of stimulatory and inhibitory cell growth factors in bovine vitreous. Exp Eye Res 1982;34:267-286.

65 Lean JS, van der Zee WA, Ryan SJ: Experimental model of proliferative vitreoretinopathy (PVR) in the vitrectomised eye: effect of silicone oil. Br J Ophthalmol 1984;68:332335.

66 Hida T, Chandler DB, Sheta SM: Classification of the stages of proliferative vitreoretinopathy in a refined experimental model in the rabbit eye. Graefes Arch Clin Exp Ophthalmol 1987;225:303-307.

-67 Chandler DB, Quansah FA, Hida T, Machemer R: A refined experimental model for proliferative vitreoretinopathy. Graefes Arch Clin Exp Ophthalmol 1986;224:86-91.

68 Pastor JC, Rodriguez E, Marcos MA, Lopez MI: Combined pharmacologic therapy in a rabbit model of proliferative vitreoretinopathy (PVR). Ophthalmic Res 2000;32:25-29.

-69 Kim B, Abdel-Rahman MH, Wang T, Pouly S, Mahmoud AM, Cebulla CM: Retinal MMP12, MMP-13, TIMP-1, and TIMP-2 expression in murine experimental retinal detachment. Invest Ophthalmol Vis Sci 2014;55: 2031-2040.

-70 Cebulla CM, Ruggeri M, Murray TG, Feuer WJ, Hernandez E: Spectral domain optical coherence tomography in a murine retinal detachment model. Exp Eye Res 2010;90:521527.

71 Hiscott PS, Grierson I, McLeod D: Retinal pigment epithelial cells in epiretinal membranes: an immunohistochemical study. $\mathrm{Br} \mathrm{J}$ Ophthalmol 1984;68:708-715.

72 Lei H, Rheaume MA, Kazlauskas A: Recent developments in our understanding of how platelet-derived growth factor (PDGF) and its receptors contribute to proliferative vitreoretinopathy. Exp Eye Res 2010;90:376-381.
Amarnani D, Machuca-Parra AI, Wong LL, Marko CK, Stefater JA, Stryjewski TP, Eliott D, Arboleda-Velasquez JF, Kim LA: Effect of methotrexate on an in vitro patient-derived model of proliferative vitreoretinopathy. Invest Ophthalmol Vis Sci 2017;58:3940-3949.

74 Hart PH, Vitti GF, Burgess DR, Whitty GA, Piccoli DS, Hamilton JA: Potential antiinflammatory effects of interleukin 4: suppression of human monocyte tumor necrosis factor alpha, interleukin 1, and prostaglandin E2. Proc Natl Acad Sci USA 1989;86:3803-3807.

75 Hermsen VM, Fulcher SF, Spiekerman AM, Phinizy JL, Di Tullio NW: Long-term inhibition of cellular proliferation by immunotoxins. Arch Ophthalmol 1990;108:1009-1011.

76 Davis AA, Whidby DE, Privette T, Houston LL, Hunt RC: Selective inhibition of growing pigment epithelial cells by a receptor-directed immunotoxin. Invest Ophthalmol Vis Sci 1990;31:2514-2519.

77 Oleszak E: Inhibition of mitogenic activity of PDGF, EGF, and FGF by interferon-gamma. Exp Cell Res 1988;179:575-580.

78 Hou J, Li Y, Zhou Z, Valiaeva N, Beadle JR, Hostetler K, Freeman WR, Hu DN, Chen H, Cheng L: Antiproliferative property of hexadecyloxypropyl 9-(2-[phosphonomethoxy] ethyl) guanine (HDP-PMEG) for unwanted ocular proliferation. Mol Vis 2011;17:627637.

79 Khoroshilova-Maslova IP, Leparskaya NL, Nabieva MM, Andreeva LD: Experimental modeling of proliferative vitreoretinopathy: an experimental morphological study. Bull Exp Biol Med 2015;159:100-102.

-80 Agrawal RN, He S, Spee C, Cui JZ, Ryan SJ, Hinton DR: In vivo models of proliferative vitreoretinopathy. Nat Protoc 2007;2:67-77.

81 Cleary PE, Ryan SJ: Experimental posterior penetrating eye injury in the rabbit. 1. Method of production and natural history. $\mathrm{Br} \mathrm{J}$ Ophthalmol 1979;63:306-311.

82 Cleary PE, Ryan SJ: Experimental posterior penetrating eye injury in the rabbit. 2. Histology of wound, vitreous, and retina. $\mathrm{Br} \mathrm{J} \mathrm{Oph-}$ thalmol 1979;63:312-321.

83 Miller W, Makova KD, Nekrutenko A, Hardison RC: Comparative genomics. Annu Rev Genomics Hum Genet 2004;5:15-56.

84 Umazume K, Barak Y, McDonald K, Liu L, Kaplan HJ, Tamiya S: Proliferative vitreoretinopathy in the swine: a new model. Invest Ophthalmol Vis Sci 2012;53:4910-4916.

85 Hou H, Huffman K, Rios S, Freeman WR, Sailor MJ, Cheng L: A novel approach of daunorubicin application on formation of proliferative retinopathy using a porous silicon controlled delivery system: pharmacodynamics. Invest Ophthalmol Vis Sci 2015;56:2755-2763.

-86 Cardillo JA, Farah ME, Mitre J, Morales PH, Costa RA, Melo LA, Kuppermann B, Jorge R, Ashton P: An intravitreal biodegradable sustained release naproxen and 5-fluorouracil system for the treatment of experimental post-traumatic proliferative vitreoretinopathy. Br J Ophthalmol 2004;88:1201-1205.
87 Mandava N, Blackburn P, Paul DB, Wilson MW, Read SB, Alspaugh E, Tritz R, Barber JR, Robbins JM, Kruse CA: Ribozyme to proliferating cell nuclear antigen to treat proliferative vitreoretinopathy. Invest Ophthalmol Vis Sci 2002;43:3338-3348.

-88 Yang CH, Huang TF, Liu KR, Chen MS, Hung PT: Inhibition of retinal pigment epithelial cell-induced tractional retinal detachment by disintegrins, a group of Arg-GlyAsp-containing peptides from viper venom. Invest Ophthalmol Vis Sci 1996;37:843-854.

89 Pinon RM, Pastor JC, Saornil MA, Goldaracena MB, Layana AG, Gayoso MJ, Guisasola $\mathrm{J}$ : Intravitreal and subretinal proliferation induced by platelet-rich plasma injection in rabbits. Curr Eye Res 1992;11:1047-1055.

90 Ryan SJ: Traction retinal detachment: XLIX Edward Jackson memorial lecture. Am J Ophthalmol 1993;115:1-20.

91 Canto Soler MV, Gallo JE, Dodds RA, Suburo AM: A mouse model of proliferative vitreoretinopathy induced by dispase. Exp Eye Res 2002;75:491-504.

92 Kono T, Kohno T, Inomata H: Epiretinal membrane formation: light and electron microscopic study in an experimental rabbit model. Arch Ophthalmol 1995;113:359-363.

$\$ 93$ Evans RA, Tian YC, Steadman R, Phillips AO: TGF-beta1-mediated fibroblast-myofibroblast terminal differentiation-the role of Smad proteins. Exp Cell Res 2003;282:90100.

-94 Dooley S, Hamzavi J, Breitkopf K, Wiercinska E, Said HM, Lorenzen J, Ten Dijke P, Gressner AM: Smad7 prevents activation of hepatic stellate cells and liver fibrosis in rats. Gastroenterology 2003;125:178-191.

-95 Saika S, Yamanaka O, Nishikawa-Ishida I, Kitano A, Flanders KC, Okada Y, Ohnishi Y, Nakajima Y, Ikeda K: Effect of Smad7 gene overexpression on transforming growth factor beta-induced retinal pigment fibrosis in a proliferative vitreoretinopathy mouse model. Arch Ophthalmol 2007;125:647-654.

-96 Sugita G, Tano Y, Machemer R, Abrams G Claflin A, Fiorentino G: Intravitreal autotransplantation of fibroblasts. Am J Ophthalmol 1980;89:121-130.

-97 Sunalp M, Wiedemann P, Sorgente N, Ryan SJ: Effects of cytotoxic drugs on proliferative vitreoretinopathy in the rabbit cell injection model. Curr Eye Res 1984;3:619-623.

98 Khanum BN, Guha R, Sur VP, Nandi S, Basak SK, Konar A, Hazra S: Pirfenidone inhibits post-traumatic proliferative vitreoretinopathy. Eye (Lond) 2017;31:1317-1328.

-99 Fastenberg DM, Diddie KR, Dorey K, Ryan SJ: The role of cellular proliferation in an experimental model of massive periretinal proliferation. Am J Ophthalmol 1982;93: 565-572.

100 Wiedemann P, Sorgente N, Ryan SJ: Proliferative vitreoretinopathy: the rabbit cell injection model for screening of antiproliferative drugs. J Pharmacol Methods 1984;12: 69-78. 
101 Rahimy MH, Peyman GA, Fernandes ML, el-Sayed SH, Luo Q, Borhani H: Effects of an intravitreal daunomycin implant on experimental proliferative vitreoretinopathy: simultaneous pharmacokinetic and pharmacodynamic evaluations. J Ocul Pharmacol 1994;10:561-570.

102 Sakamoto T, Kimura H, Scuric Z, Spee C, Gordon EM, Hinton DR, Anderson WF, Ryan SJ: Inhibition of experimental proliferative vitreoretinopathy by retroviral vector-mediated transfer of suicide gene: can proliferative vitreoretinopathy be a target of gene therapy? Ophthalmology 1995;102: 1417-1424.

103 Hui YN, Goodnight R, Sorgente N, Ryan SJ: Fibrovascular proliferation and retinal detachment after intravitreal injection of activated macrophages in the rabbit eye. Am J Ophthalmol 1989;108:176-184.
104 Wong CA, Potter MJ, Cui JZ, Chang TS, Ma $\mathrm{P}$, Maberley AL, Ross WH, White VA, Samad A, Jia W, Hornan D, Matsubara JA: Induction of proliferative vitreoretinopathy by a unique line of human retinal pigment epithelial cells. Can J Ophthalmol 2002;37:211220.

105 Borhani H, Peyman GA, Rahimy MH, Thompson H: Suppression of experimental proliferative vitreoretinopathy by sustained intraocular delivery of 5-FU. Int Ophthalmol 1995;19:43-49.

106 Weinsieder A, Radtke ND, Currier GJ, Caple S, Presley E, Weinsieder G: Bovine RPE heterotransplants simulate proliferative vitreoretinopathy (PVR) in rabbits. Metab Pediatr Syst Ophthalmol 1987;10:2-8.

107 Iverson D DW, Hartzer M: Pars plana lensectomy, vitrectomy and transvitreous diathermy in the rabbit eye: a model of PVR. Invest Ophthalmol Vis Sci 1991;32:856.
08 Yang CS, Khawly JA, Hainsworth DP, Chen SN, Ashton P, Guo H, Jaffe GJ: An intravitreal sustained-release triamcinolone and 5 -fluorouracil codrug in the treatment of experimental proliferative vitreoretinopathy. Arch Ophthalmol 1998;116:69-77.

109 Shinohara K, Tanaka M, Sakuma T, Kobayashi Y: Efficacy of daunorubicin encapsulated in liposome for the treatment of proliferative vitreoretinopathy. Ophthalmic Surg Lasers Imaging 2003;34:299-305.

110 Kuo HK, Chen YH, Wu PC, Wu YC, Huang F, Kuo CW, Lo LH, Shiea J: Attenuated glial reaction in experimental proliferative vitreoretinopathy treated with liposomal doxorubicin. Invest Ophthalmol Vis Sci 2012;53: $3167-3174$ 